\title{
Transport of Benzoic and Propanoic Acids by Zygosaccharomyces bailii
}

\author{
By ALAN D. WARTH \\ CSIRO Division of Food Processing, PO Box 52, North Ryde, NSW 2113, Australia
}

(Received 9 August 1988; accepted 30 November 1988)

\begin{abstract}
Uptake rates of benzoic and propanoic acid into Zygosaccharomyces bailii were proportional to the concentration of undissociated acid and showed no indication of limitation at high concentrations. Benzoic acid permeated 27 times faster than propanoic acid. Other low- $M_{\mathrm{r}}$ fatty acids were taken up at rates approximately related to their lipophilicity. Glucose stimulated uptake rate and inhibitors of glucose transport or metabolism removed the stimulation. It was concluded that the principal mechanism of uptake was diffusion of undissociated acid. The $Z$. bailii membrane had lower permeabilities than reported for other cell types and lipid bilayers. Growth in the presence of benzoic acid reduced permeability to benzoic acid further. Preservative-resistant yeast species had lower uptake rates of propanoic acid than sensitive ones. Degradation of the cell wall did not change the permeability to propanoic acid.
\end{abstract}

\section{INTRODUCTION}

The yeast $Z$ ygosaccharomyces bailii is very tolerant of the common weak-acid-type preservatives - benzoic, sorbic, propanoic and acetic acids and $\mathrm{SO}_{2}$ - and often causes spoilage of acid foods and beverages containing these preservatives (Thomas \& Davenport, 1985; Warth, $1986 \mathrm{~b}$ ). It is commonly accepted that lipophilic acids can permeate cell membranes passively in their undissociated form (Stein, 1981). Active transport systems for benzoic acid and for the aliphatic acids are also well known. At preservative concentrations used for growth inhibition, active transport is not likely to be important. Previous studies on the mechanism of uptake of benzoic acid (Macris, 1975) and of $\mathrm{SO}_{2}$ (Macris \& Markarkis, 1974) in Saccharomyces cerevisiae were interpreted as indicating active transport systems, although Stratford \& Rose (1986) concluded that transport of $\mathrm{SO}_{2}$ in $S$. cerevisiae was by simple diffusion.

Cells of $Z$. bailii grown in the presence of several weak-acid-type preservatives maintained, in the presence of an energy supply, a low intracellular concentration of preservative anion (Warth, 1977), and were more resistant to preservatives (Warth, $1986 a, b$ ). It was proposed that adapted cells formed a transport system for preservative anion, and that a major part of the effect of preservatives was the energy requirement to maintain a lowered intracellular preservative concentration. According to this model, the rate at which preservative enters the cell determines the energy demand and may influence the steady-state level of preservative anion in the cytoplasm. Knowledge of the rate, energetics and specificity of uptake of preservatives is therefore most important in elucidating mechanisms of preservative action, and in predicting the effects of conditions and different preservatives. Differences in the rate of uptake of preservative may explain differences in resistance between yeast species and the increased resistance of $Z$. bailii when grown in the presence of preservatives. Benzoic acid is the preservative most commonly used in low-pH products; however, it is taken up very rapidly by yeasts (Macris, 1975; Warth, 1977). Propanoic acid typifies the straight-chain aliphatic series of preservatives and has been used for much of this study as it permeates more slowly, allowing more accurate determination of kinetics.

\section{METHODS}

Growth. Zygosaccharomyces bailii FRR 1292 and other yeasts (see Table 4) were grown on 5\%(w/v) glucoseyeast extract medium, pH 3.5 , at $25^{\circ} \mathrm{C}$ (Warth, 1985). Minimum inhibitory concentrations (MICs) of benzoic acid 
were determined using microwell plates inoculated with exponential-phase cultures grown in the presence of benzoic acid (Warth, 1986a). Mid-exponential-phase cells, 0.2-1.0 mg dry wt (1 culture)-1, were used for all experiments apart from the preparation of spheroplasts. Cells were centrifuged, washed twice with $0.05 \mathrm{M}$ potassium citrate buffer $\mathrm{pH} 3 \cdot 5$ and stored for up to $3 \mathrm{~h}$ at $5-10^{\circ} \mathrm{C}$.

Preservative uptake. Suspensions $(2.0 \mathrm{ml})$ containing $12-24 \mathrm{mg}$ dry wt of cells in $0.1 \mathrm{M}$-potassium citrate $\mathrm{pH} 3.50$ were incubated together with any additions at $25 \pm 0.2{ }^{\circ} \mathrm{C}$ for $15 \mathrm{~min}$. The reaction was started by the addition of $20 \mu 110 \mathrm{~mm}$-preservative. Samples $(200 \mu \mathrm{l})$ were filtered on $0.4 \mu \mathrm{m}$ polycarbonate filters (Nuclepore) at intervals of approximately $15 \mathrm{~s}$ for benzoic and $30 \mathrm{~s}$ for propanoic acid, and the times at which each filtration was complete were noted. Filtration took from 1 to $1.5 \mathrm{~s}$. More accurate and reproducible results were obtained by not washing the filter but applying corrections for the volume retained on the filter $(0 \cdot 14 \mu \mathrm{l})$, the interstitial volume of the cells $\left[1.0 \mu \mathrm{l}(\mathrm{mg} \text { dry } \mathrm{wt})^{-1}\right]$ and the volume of cell ater $\left[1.8 \mu \mathrm{l}\left(\mathrm{mg} \mathrm{dry} \mathrm{wt}^{-1}\right]\right.$. This was possible because of the low volume of filtrate retained on this type of filter and the high uptake of preservative. Data were generally consistent with first-order kinetics. Uptake rate constants were calculated for each time interval, using the maximum uptake determined from samples taken at 10 and $15 \mathrm{~min}$. In some circumstances where maximum uptake was not measured or was not constant, a value for maximum uptake was assumed so as to give a qualitative best fit. Values from data obtained at up to $50 \%$ of maximum uptake were averaged. Concentrations of preservative refer to the total concentration of dissociated plus undissociated forms.

Cell water, the interstitial volume and filter hold-up volumes were determined using $\left[1-{ }^{14} \mathrm{C}\right]$ sorbitol (Amersham).

Permeability. The permeability of the cell surface was calculated from the uptake rate per mg dry wt, the area of the cell membrane, and the cell dry weight. Cell dimensions were measured using phase-contrast optics at $\times 2000$ magnification. Nearly all cells and buds of $Z$. bailii closely approximated prolate ellipsoids. A cell wall thickness of $125 \mathrm{~nm}$ was assumed and volume and membrane area were calculated for each cell as prolate ellipsoids. Cell weight was calculated from the volume using a relative density of 1.096 , determined by density-gradient centrifugation in Urographin.

Analyses. Propanoic and benzoic acids were determined by liquid scintillation counting using $\left[11^{-14} \mathrm{C}\right]$ propanoate and $\left[7^{-14} \mathrm{C}\right.$ ) benzoate respectively $\left(1 \mathrm{GBq} \mathrm{mol}{ }^{-1}\right.$, New England Nuclear). Sorbic acid was determined by HPLC at $250 \mathrm{~nm}$ using an RP8 reverse-phase column $(250 \times 3.7 \mathrm{~mm})$ eluted with $50 \%(\mathrm{v} / \mathrm{v})$ methanol in $1 \%$ acetic acid. The other low- $M_{\mathrm{r}}$ fatty acids were determined by gas chromatography using Chromosorb 101 at $170^{\circ} \mathrm{C}$ and $185^{\circ} \mathrm{C}$.

Effect of concentration. Solutions of potassium benzoate $(0.20 \mathrm{ml})$ containing $0 \cdot 1 \mathrm{MBq}\left[7^{-14} \mathrm{C}\right]$ benzoate, and $\mathrm{HCl}$ $(20 \mu \mathrm{l})$ equivalent to $80 \%$ of the potassium benzoate, were added simultaneously to $1.8 \mathrm{ml}$ of the cell suspension. To avoid the effects of rapid osmotic changes at the higher concentrations tested with propanoic acid, the cells were incubated with potassium propanoate $\mathrm{pH} 3.5$ for $15 \mathrm{~min}$ prior to the addition of $\left[{ }^{14} \mathrm{C}\right]$ propanoate $(0.4 \mathrm{MBq})$.

Uptake of fatty acids. A mixture of propanoic, 1-methylpropanoic and butanoic acids $(0.5 \mathrm{M})$ was adjusted to $\mathrm{pH}$ 3.5 , and added to the cell suspension to give an initial concentration of $5 \mathrm{~mm}$ each. In a separate incubation, a $100 \mathrm{~mm}$ solution of the potassium salts of pentanoic, hexanoic and sorbic acids was added to give $1 \mathrm{~mm}$ initial concentration of each in the cell suspension. Final concentrations were $3.4 \mathrm{~mm}$ for the first experiment and $0.55 \mathrm{~mm}$ for the second. Uptake was expressed relative to the concentration in the supernatant. Cells plus filters were extracted at $65^{\circ} \mathrm{C}$ for $3 \mathrm{~min}$ with $100 \mu 10.2 \mathrm{M}-\mathrm{K}_{2} \mathrm{CO}_{3}$ containing $1.0 \mathrm{~mm}$-2-methylbutanoate as internal standard. The suspension was centrifuged after removal of the filters. A sample of the supernatant was acidified with 0.1 vol. $50 \% \mathrm{H}_{2} \mathrm{SO}_{4}$ plus $1 \% \mathrm{H}_{3} \mathrm{PO}_{4}$ and centrifuged; fatty acids were determined by gas chromatography and sorbic acid by HPLC.

Spheroplasts. Spheroplasts were prepared from a late-exponential-phase culture $\left(2.8 \mathrm{~g}\right.$ dry wt $\left.1^{-1}\right)$ using modifications of the method of Dickinson \& Isenberg (1982). Cells were centrifuged and washed twice in $0 \cdot 1 \mathrm{M}-$ MES/0.1 M-EDTA, pH 6.0, and incubated $\left(75 \mathrm{mg}^{2}\right.$ wet wt ml ${ }^{-1}$ ) with $1 \mathrm{mg}$ dithiothreitol $\mathrm{ml}^{-1}$ in this buffer at $30^{\circ} \mathrm{C}$ with stirring for $30 \mathrm{~min}$. A sample was taken and washed in $0.6 \mathrm{M}-\mathrm{KCl} / 0.1 \mathrm{M}$-potassium citrate pH 3.5 before determination of propanoic acid uptake rate. These cells appeared normal by phase-contrast microscopy in water. The remainder were washed with $20 \mathrm{~mm}$-citrate/phosphate $\mathrm{pH} 5.85 \mathrm{in} 0.6 \mathrm{M}-\mathrm{KCl}$ and incubated in this buffer with $2 \mathrm{mg}$ Novozym $234 \mathrm{ml}^{-1}$ (Novo Enzyme Products, UK) at $25^{\circ} \mathrm{C}$ with stirring. After $2 \mathrm{~h}, 74 \%$ of the cells were spherical and lysed on dilution with water, $24 \%$ were lysed and $2 \%$ retained their ovoid or budding shape. The suspension was then diluted slowly into $0.6 \mathrm{M}-\mathrm{KCl} / 0 \cdot 1 \mathrm{M}$-potassium citrate $\mathrm{pH} 3 \cdot 5$, centrifuged and washed three times to remove lysed cells. Propanoic acid uptake was determined for spheroplasts, dithiothreitol-treated cells and untreated cells in $0.6 \mathrm{M}-\mathrm{KCl} / 0.1 \mathrm{M}$-potassium citrate $\mathrm{pH} 3.5$.

\section{RESULTS}

Uptake kinetics and cell permeability. Uptake of benzoic and propanoic acids is shown in Fig. 1. Each followed first-order kinetics for at least the first $50 \%$ of the reaction. The uptake 


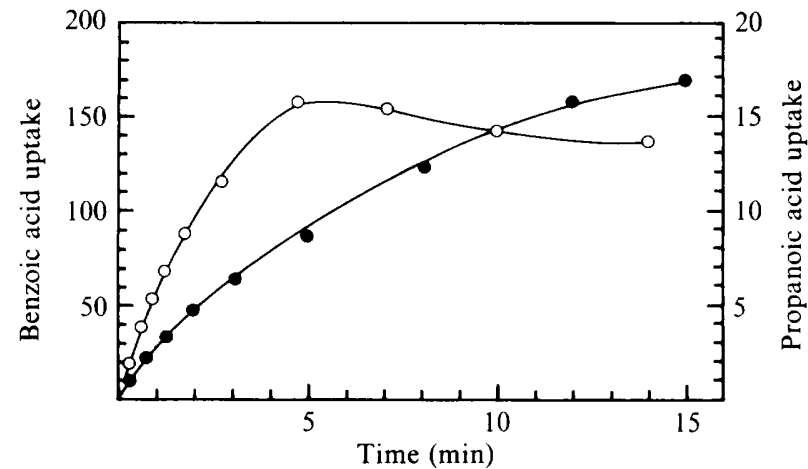

Fig. 1. Kinetics of uptake of benzoic acid (O) and propanoic acid (O) into $Z$. bailii at $25^{\circ} \mathrm{C}$. Uptake, expressed as nmol ( $\mathrm{mg}$ dry $\mathrm{wt})^{-1} \mathrm{~min}^{-1}$, was normalized by dividing by the actual concentration (mM) of preservative in the supernatant. The initial concentration was $0.1 \mathrm{~mm}$.

Table 1. Effect of various compounds on rates of uptake of benzoic and propanoic acids by Z. bailii

Results are expressed as percentages of the respective value obtained in $0 \cdot 1 \mathrm{M}$-citrate $\mathrm{pH} 3 \cdot 50$, and are shown \pm SEM when at least three determinations on separate cell crops were averaged. Control values of uptake rates of benzoic and propanoic acids for cells grown in the absence of preservative were $86 \pm 11$ and $3.2 \pm 0.37 \mathrm{nmol}(\mathrm{mg} \text { dry } \mathrm{wt})^{-1}(\mathrm{mM} \text { undissociated acid in supernatant })^{-1} \mathrm{~min}^{-1}$ respectively. For cells grown in the presence of benzoic acid, the uptake rates were $49 \pm 6$ and $2 \cdot 9 \pm 0.3 \mathrm{nmol} \mathrm{mg}^{-1} \mathrm{~mm}^{-1}$ $\min ^{-1}$ respectively.

Addition

None

$2.5 \%$ n-butanol

$5 \%$ glucose

$5 \%$ glucose +2 mm-iodoacetate

$5 \%$ glucose +4 mu-uranyl nitrate

$5 \%$ 2-deoxyglucose

2 mM-iodoacetate

4 mM-uranyl nitrate

$0.1 \mathrm{mM}-p$-chloromercuribenzoate

$\overbrace{\begin{array}{c}\text { Benzoic } \\ \text { acid }\end{array}}^{\begin{array}{c}\text { Cells grown without } \\ \text { added preservative }\end{array}}$

$\begin{array}{lc}100 & 100 \\ 164 \pm 25 & 202 \pm 30 \\ 215 \pm 24 & 158 \pm 17 \\ 130 & \\ 129 & \\ 110 & 133 \pm 16 \\ 91 & 98 \\ & 102 \\ & 94\end{array}$

$\overbrace{\begin{array}{c}\text { Benzoic } \\ \text { acid }\end{array}}^{\text {Cells grown with }} \begin{gathered}\begin{array}{c}\text { Propanoic } \\ \text { acid }\end{array} \\ 2 \text { mm-benzoic acid }\end{gathered}$

100

100

167

128

144

86

81

75

94

rate constant for benzoic acid $\left[86 \pm 11 \mathrm{nmol}(\mathrm{mg} \text { dry } \mathrm{wt})^{-1}\right.$ (mM undissociated acid in the supernatant $\left.)^{-1} \mathrm{~min}^{-1}\right]$, was considerably greater than that of propanoic acid $(3 \cdot 2 \pm 0 \cdot 37)$. The average total cell volume and the average area of the membrane, determined from light microscope measurements and the cell density, were $65 \cdot 8 \pm 4 \mu \mathrm{m}^{3}$ and $82 \cdot 7 \pm 6 \mu \mathrm{m}^{2}$ respectively. From these data, permeabilities of the membrane to benzoic acid and propanoic acid of $26.9 \pm 5 \times 10^{-8} \mathrm{~m} \mathrm{~s}^{-1}$ and $1.55 \pm 0.2 \times 10^{-8} \mathrm{~m} \mathrm{~s}^{-1}$ respectively were calculated.

Cells grown in the presence of $2 \mathrm{~mm}$-benzoic acid (adapted cells) had a slightly (10\%) smaller membrane area and no significant difference in their permeability to propanoic acid. Permeability to benzoic acid, however, was $40 \%$ less.

Effect of various compounds on uptake rate. Butanol substantially increased the rates of uptake of both benzoic and propanoic acids (Table 1). Uptake rate was also stimulated by glucose, the effect being largely removed by the simultaneous addition of iodoacetate or uranyl nitrate. In the absence of glucose, deoxyglucose and other inhibitors of glycolysis or transport did not greatly affect uptake rates. 


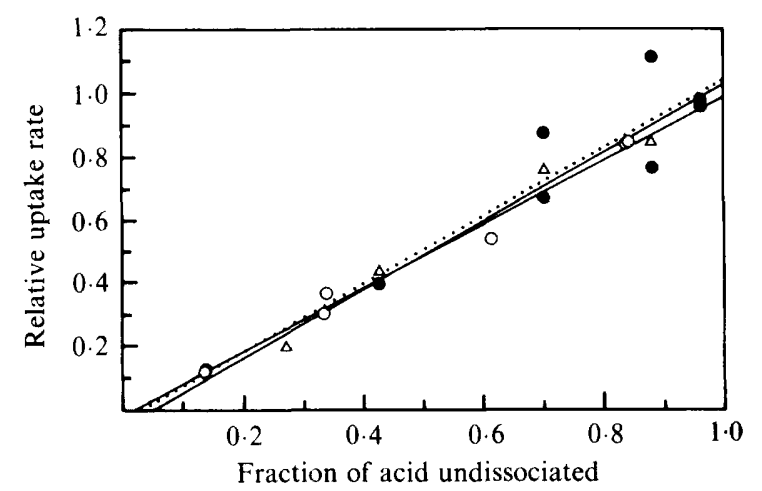

Fig. 2. Rates of uptake at various $\mathrm{pH}$ values, plotted against the fraction of acid undissociated at that $\mathrm{pH}$. Control values, from the regression for each experiment, are expressed as nmol (mg dry wt $)^{-1}$ $\min ^{-1}$, normalized by dividing by the concentration (mM) of undissociated preservative in the supernatant: benzoic acid, $91.5(\mathrm{O})$; propanoic acid, $4.11(\mathrm{O})$; benzoic acid with cells grown in $2 \mathrm{mM}$ benzoic acid, $33 \cdot 3(\triangle)$.

Table 2. Effect of various compounds on the maximum amount of benzoic and propanoic acids accumulated by $Z$. bailii

Results are the maximum uptake observed during the kinetic experiments in Table 1, and are expressed as percentages of the respective value obtained in $0.1 \mathrm{M}$-citrate $\mathrm{pH} 3.50$. Under these conditions, cells grown in the absence of benzoic acid accumulated benzoic and propanoic acids to $155 \pm 36$ and $18.5 \pm 0.7 \mathrm{nmol}(\mathrm{mg} \text { dry } \mathrm{wt})^{-1}$ respectively; cells grown in the presence of $2 \mathrm{~mm}$-benzoic acid accumulated the acids to $75 \pm 19$ and $19 \pm 1 \mathrm{nmol}(\mathrm{mg} \mathrm{dry} \mathrm{wt})^{-1}$ respectively. These control values are normalized by dividing by the concentration $(\mathrm{mM})$ of preservative in the supernatant, and are given \pm SEM for three determinations on the same preparation of cells.

\begin{tabular}{|c|c|c|c|c|}
\hline \multirow[b]{2}{*}{ Addition } & \multicolumn{2}{|c|}{$\begin{array}{l}\text { Cells grown without } \\
\text { added preservative }\end{array}$} & \multicolumn{2}{|c|}{$\begin{array}{l}\text { Cells grown with } \\
2 \text { mM-benzoic acid }\end{array}$} \\
\hline & $\begin{array}{l}\text { Benzoic } \\
\text { acid }\end{array}$ & $\begin{array}{l}\text { Propanoic } \\
\text { acid }\end{array}$ & $\begin{array}{l}\text { Benzoic } \\
\text { acid }\end{array}$ & $\begin{array}{l}\text { Propanoic } \\
\text { acid }\end{array}$ \\
\hline None & 100 & 100 & 100 & 100 \\
\hline $2 \cdot 5 \%$ n-butanol & 28 & 56 & & 108 \\
\hline $5 \%$ glucose & 97 & 225 & 13 & 48 \\
\hline $5 \%$ glucose $+2 \mathrm{~mm}$-iodoacetate & 134 & & & \\
\hline $5 \%$ glucose +4 mu-uranyl nitrate & 84 & & & \\
\hline $5 \%$ 2-deoxyglucose & 68 & 60 & & 71 \\
\hline 2 mM-iodoacetate & 47 & 61 & & 71 \\
\hline 4 mM-uranyl nitrate & & 59 & & 51 \\
\hline $0 \cdot 1 \mathrm{mM}$-p-chloromercuribenzoate & & 48 & & 89 \\
\hline
\end{tabular}

Effect of various compounds on amount of uptake. Unadapted cells accumulated benzoate and propanoate (Table 2). Calculation of the apparent internal pHs, assuming impermeability of the anions, gave values of 6.20 and 6.02 respectively. Measurement by freeze-thawing gave a value of $5.95 \pm 0 \cdot 15$. Adapted cells in the absence of glucose also accumulated high levels of both benzoate and propanoate, but these were considerably reduced in the presence of glucose. Internal pHs, in the absence and presence of glucose, were $6.13 \pm 0.2$ and $6.51 \pm 0.27$ respectively.

Effect of $\mathrm{pH}$, concentration and temperature. Uptake rates were proportional to the fraction of the acid which was undissociated (Fig. 2). There was no positive intercept on the $y$ axis, showing that the anion was not taken up at a rate comparable with that of the undissociated form. Uptake rate constants for both benzoic acid and propanoic acid were essentially independent of the concentration in the medium over a wide range (Fig. 3). In particular, there was no evidence 


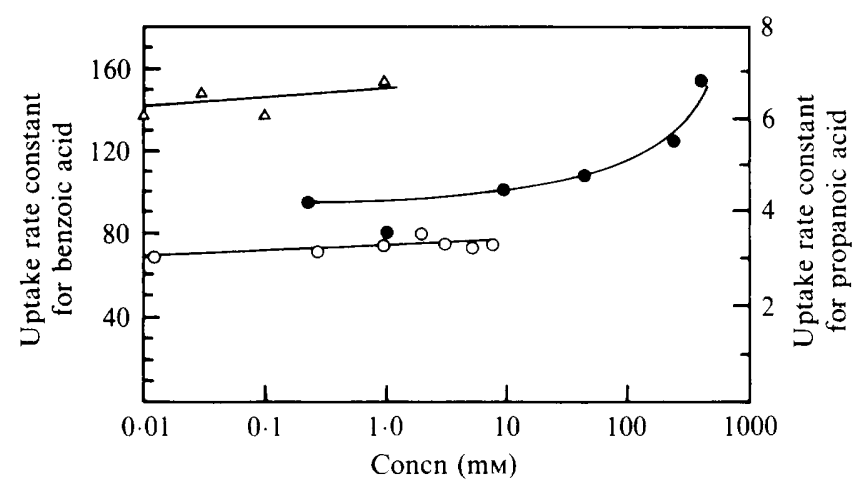

Fig. 3. Effect of concentration on the uptake rate constant. Uptake, expressed as nmol (mg dry wt $)^{-1}$ $\mathrm{min}^{-1}$, was normalized by dividing by the actual concentration (mM) of preservative in the supernatant. $\bigcirc$, Benzoic acid; $\bigcirc$, propanoic acid; $\triangle$, benzoic acid with cells grown in $2 \mathrm{~mm}$-benzoic acid.

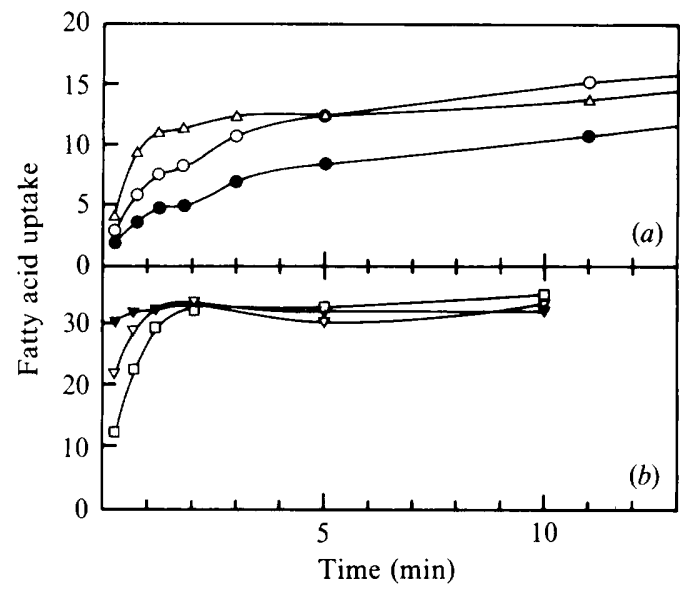

Fig. 4 Uptake of low- $M_{\mathrm{r}}$ fatty acids by $Z$. bailii. (a) Propanoic (O), 2-methylpropanoic (O), and butanoic $(\triangle)$ acids. Intitial concentrations, $5 \mathrm{~mm}$. (b) Pentanoic $(\square)$, hexanoic $(\nabla)$ and sorbic $(\nabla)$ acids. Initial concentrations, $1 \mathrm{~mm}$. Uptake is expressed as nmol (mg dry wt $)^{-1}$, normalized by dividing by the actual concentration (mM) of preservative in the supernatant.

for a rate limitation at high preservative concentrations. The data in fact showed an increase. For adapted cells in the presence of glucose, the rate of benzoic acid uptake was proportional to the concentration of undissociated acid (Fig. 2), and the rate constant was independent of concentration over the range tested (Fig. 3).

The Arrhenius plot for propanoic acid uptake rate in $Z$. bailii was linear between $0.5^{\circ} \mathrm{C}$ and $25^{\circ} \mathrm{C}\left(r^{2}=0.99\right)$ and showed an activation energy of $105 \mathrm{~kJ} \mathrm{~mol}^{-1}$. Two other yeasts, Hansenula anomala and Kluyveromyces fragilis, were also studied and gave values of 89 and $118 \mathrm{~kJ} \mathrm{~mol}^{-1}$ respectively.

Uptake of other low- $M_{\mathrm{r}}$ fatty acids. For the saturated straight-chain acids, uptake rate increased with chain length (Fig. 4). 2-Methylpropanoic acid was taken up more slowly than propanoic or butanoic acid. Sorbic acid (2,4-hexadienoic acid) was taken up more rapidly than hexanoic acid.

Effect of treatment with cell wall reagents on uptake. In order to determine if the permeation of weak-acid preservatives was limited by the cell wall or by the membrane, spheroplasts were prepared. Treatment of $Z$. bailii with dithiothreitol had no effect on the permeability (Table 3) or 
Table 3. Effect of treatment with cell-wall-degrading agents on the rate of uptake of propanoic acid by $Z$. bailii

$\begin{array}{lccc}\text { Treatment } & \begin{array}{c}10^{-7} \times \text { No. of } \\ \text { cells ml }\end{array} & \begin{array}{c}\text { Uptake } \\ \text { rate }\end{array} & \begin{array}{c}\text { Corrected } \\ \text { rate }\end{array} \\ \text { None } & 5.0 & 3.8 & 3.8 \\ \text { Dithiothreitol } & 5.1 & 3.8 & 3.7 \\ \text { Dithiothreitol } & 1.95 & 1.13 & 2.9\end{array}$

\footnotetext{
* Number of cells or spheroplasts per mg dry cells prior to treatment.

$\dagger$ Units: $\mathrm{nmol}\left(\mathrm{mg}\right.$ dry wt untreated cells) ${ }^{-1} \mathrm{~min}^{-1}$, normalized by dividing by the concentration (mM) of preservative in the supernatant.

¿ Uptake rate corrected for the number of intact cells or spheroplasts.
}

Table 4. Rate of uptake of propanoic acid and sensitivity to benzoate in yeasts

$\begin{array}{lccc}\text { Organism } & \begin{array}{c}\text { FRR } \\ \text { no. }\end{array} & \begin{array}{c}\text { MIC of } \\ \text { benzoic acid } \\ \left(\mathrm{mg} \mathrm{l}^{-1}\right)\end{array} & \begin{array}{c}\text { Uptake rate cons } \\ \text { for propanoic }\end{array} \\ \text { omyces cerevisiae } & 1297 & 170 & 60 \\ \text { myces fragilis } & 1338 & 170 & 41 \\ \text { ra apiculata } & 2168 & 190 & 86 \\ \text { ula anomala } & 2169 & 220 & 59 \\ \text { romyces cerevisiae } & 1298 & 290 & 20 \\ \text { krusei } & 1302 & 440 & 15 \\ \text { omycodes ludwigii } & 2294 & 650 & 6.4 \\ \text { accharomyces pombe } & 2535 & 570 & 2.7 \\ \end{array}$

${ }^{*}$ Units : nmol (mg dry $\left.\mathrm{wt}\right)^{-1} \mathrm{~min}^{-1}$, normalized by dividing by the concentration (mM) of preservative in the supernatant.

appearance of the cells. Subsequent treatment with Novozym converted nearly all the cells into osmotically sensitive spheroplasts. This suspension had a substantially lower uptake rate. After correction for the number of intact spheroplasts the rate was still less than in untreated cells, indicating that an intact cell wall structure is not important in determining the permeability of the cell to preservatives.

Uptake rate in other yeast species. Generally, propanoic acid was taken up more rapidly in yeasts that were relatively sensitive to preservative, while species that were tolerant of preservative had low uptake rates (Table 4).

\section{DISCUSSION}

The proportionality over a range of $\mathrm{pH}$ values between the rate of uptake and the concentration of undissociated acid suggests that this is the dominant form in which benzoic and propanoic acids enter the cell. This result does not exclude transport by a proton-anion symport mechanism. It was not expected that the anion transport system postulated to account for low uptake of preservative (Warth, 1977) would be demonstrable under the conditions of these experiments. Furthermore, the cells used were grown in the absence of added preservative and therefore would not be expected to have the carrier. Uptake rate was proportional to concentration over a wide range, showing no evidence for carrier limitation at high concentrations. The tendency to an increased rate suggests that high concentrations of propanoic acid disturbed the membrane structure. Butanol also increased the uptake rate, an effect that is characteristic of passive uptake through the lipid pathway, while many mediated transfer processes are inhibited (Deuticke, 1977). 
The relative rates of uptake for various acids were generally similar to the values predicted from their partition coefficients and to those found in erythrocytes (Klocke \& Flasterstein, 1982) and lipid bilayers (Wolosin \& Ginsburg, 1975; Walter \& Gutknecht, 1986), and showed no examples suggestive of a specific transport system. Minor deviations were that 2methylpropanoic acid permeated more slowly and sorbic acid more rapidly than expected from their octanol-water partition coefficients. Biological membranes generally show a greater degree of specificity (Deuticke, 1977) as diffusional and interfacial factors are also involved.

In absolute terms, the $Z$. bailii membrane was 40 -fold less permeable to propanoic acid than toad bladder (Wolosin \& Ginsburg, 1975), 1500-fold less than human erythrocyte membranes (Klocke \& Flasterstein, 1982) and 20000-fold less than phosphatidylcholine bilayers (Walter \& Gutknecht, 1986). The other yeast species studied had uptake rates up to 20 times that of $Z$. bailii. Destruction of cell wall integrity did not appear to increase the permeability of $Z$. bailii, confirming that the membrane was the rate-limiting barrier. The activation energy for propanoic acid uptake of $105 \mathrm{~kJ} \mathrm{~mol}^{-1}$ compares with values of 44 (Klocke \& Flasterstein, 1982) and $92 \mathrm{~kJ} \mathrm{~mol}^{-1}$ (Deuticke, 1977) for acetic acid permeability in erythrocytes and is similar to that of a number of other passive permeants (Deuticke, 1977). It is also consistent with, but lower than, that often found for facilitated diffusion. This high value eliminates unstirred layer effects as being rate limiting, as these have activation energies of $17-20 \mathrm{~kJ} \mathrm{~mol}^{-1}$.

The extent of uptake in uninduced cells was generally consistent with that calculated, assuming passive transport of free acid and impermeability of the anion, and values reported for the intracellular pH under the conditions of the experiment. Induced cells in the presence of glucose had much lower benzoate contents, as is consistent with efflux of preservative anions as previously proposed (Warth, 1977).

Results generally were obtained at $0.1 \mathrm{~mm}$ preservative concentration. This is advantageous in reducing possible effects of counter-ion flow, $\mathrm{pH}$ adjustment and osmotic balance. Benzoic and propanoic acids exert their preservative action on $Z$. bailii in the concentration range of 1-10 mM and 20-200 mM respectively (Warth, 1986b). Since rates were proportional to concentration, the data obtained should remain applicable at practical preservative concentrations.

The increased uptake rates observed in the presence of glucose, together with the effects of inhibitors on this increase, suggest the presence of an additional transport pathway requiring glucose transport. In several ways the system does not appear to be typical of active transport. It appears to lack specificity, as both benzoic and propanoic acid uptake rates were stimulated, there was no indication of carrier limitation at benzoic acid concentrations up to $1 \mathrm{mM}$, and it was not inducible, as the effect was seen in both unadapted and adapted cells. The response to $\mathrm{pH}$ showed that undissociated benzoic acid was the form transported. A possible alternative explanation is that the acids bound gratuitously to the glucose carrier. Further studies are required to characterize the system adequately.

The previous report of carrier-mediated transport of benzoic acid in S. cerevisiae (Macris, 1975 ) is not valid, as the conclusions were based upon uptake data taken over fixed time intervals, rather than on kinetic constants. Since benzoic acid uptake was rapid compared with the incubation time, such treatment does not give initial rates and leads to artifactual MichaelisMenten constants.

A major stress on yeasts caused by weak-acid preservatives under acid conditions is the energy demand for maintenance of intracellular $\mathrm{pH}$, while keeping the intracellular concentration of preservative anion low by allowing its exit from the cell (Warth, 1977). The maximum level of preservative that a species can tolerate may be determined by the rate at which preservative enters the cell and by the capacity of the cell to remove it. The present data for nine species of yeast showed that preservative-resistant species generally did have lower rates of uptake. Among a smaller set of species, there was no relationship between the maximum rate of energy generation and preservative resistance (Warth, 1988), suggesting that membrane permeability is of major importance in determining preservative tolerance in yeasts. The decreased permeability of cells of $Z$. bailii adapted to benzoic acid suggests that both formation of the anion transport system and a change in permeability of the membrane are responsible for the large 
increase in preservative resistance observed. It is not known what changes in membrane structure or composition are responsible for the permeability differences.

Recently it was suggested that the very rapid rate of influx of benzoic acid would make efflux of anions from the cell a futile effort (Cole \& Keenan, 1987). Efflux of anions requires energy to export an equivalent amount of protons to maintain cell $\mathrm{pH}$. An indication of the feasibility of using energy to maintain lower than equilibrium values of benzoate in the cell can be obtained by comparing the uptake rate of benzoic acid from the present results with the increase in fermentation rate caused by benzoic acid in anaerobic chemostat cultures (Warth, 1988). Assuming the production of $1 \mathrm{~mol} \mathrm{ATP} \mathrm{per} \mathrm{mol} \mathrm{CO}_{2}$ or ethanol formed, 0.7-1.8 mol ATP was utilized per mol benzoic acid taken up. This value is comparable to, but slightly lower than, that required to maintain a normal proton-motive force, and confirms the potential practicability of the mechanism. Direct measurements under identical conditions are required to show the actual stoichiometry.

Transport of $\mathrm{SO}_{2}$ in $S$. cerevisiae was studied by Stratford \& Rose (1986), who concluded that uptake was by simple diffusion of the uncharged molecular species. There is a correlation between species in resistance to $\mathrm{SO}_{2}$, benzoic acid and sorbic acid (Warth, 1985). The permeation of the undissociated form and the accumulation of anion, driven by the $\mathrm{pH}$ difference between the cell and the medium, are shared features of the antimicrobial action of the common weak-acid preservatives.

\section{REFERENCES}

Cole, M. B. \& Keenan, M. H. J. (1987). Effects of weak acids and external $\mathrm{pH}$ on the intracellular $\mathrm{pH}$ of Zygosaccharomyces bailii, and its implications in weak-acid resistance. Yeast 3, 23-32.

Deuticke, B. (1977). Properties and structural basis of simple diffusion pathways in the erythrocyte membrane. Review of Physiological and Biochemical Pharmacology 78, 1-97.

DiCKINSON, D. P. \& IsENBERG, I. (1982). Preparation of spheroplasts of Schizosaccharomyces pombe. Journal of General Microbiology 128, 651-654.

KLOCKE, R. A. \& Flasterstein, F. (1982). Kinetics of erythrocyte penetration by aliphatic acids. Journal of Applied Physiology 53, 1138-1143.

MACRIS, B. J. (1975). Mechanism of benzoic acid uptake by Saccharomyces cerevisiae. Applied Microbiology 30, 503-506.

MaCRIS, B. J. \& MARKarkis, P. (1974). Transport and toxicity of sulphur dioxide in the yeast Saccharomyces cerevisiae var. ellipsoideus. Journal of the Science of Food and Agriculture 25, 21-29.

Stein, W. D. (1981). Permeability for lipophilic molecules. In Membrane Transport, pp. 1-28. Edited by S. L. Bonting \& J. J. H. H. M. de Pont. Amsterdam: Elsevier.

Stratford, M. \& Rose, A. H. (1986). Transport of sulphur dioxide by Saccharomyces cerevisiae. Journal of General Microbiology 132, 1-6.
Thomas, D. S. \& DAVENPoRT, R. R. (1985). Zygosaccharomyces bailii - a profile of characteristics and spoilage activities. Food Microbiology 2, 157-169.

W Alter, A. \& GutKnecht, J. (1986). Permeability of small nonelectrolytes through lipid bilayer membranes. Journal of Membrane Biology 90, 207-217.

WARTH, A. D. (1977). Mechanism of resistance of Saccharomyces bailii to benzoic, sorbic and other weak acids used as food preservatives. Journal of Applied Bacteriology 43, 215-230.

WARTH, A. D. (1985). Resistance of yeast species to benzoic and sorbic acids and to sulfur dioxide. Journal of Food Protection 48, 564-569.

WARTH, A. D. (1986a). Effect of nutrients and pH on the resistance of $Z$ ygosaccharomyces bailii to benzoic acid. International Journal of Food Microbiology 3, 263-271.

WARTH, A. D. $(1986 b)$. Preservative resistance of Zygosaccharomyces bailii and other yeasts. CSIRO Food Research Quarterly 46, 1-8.

WARTH, A. D. (1988). Effect of benzoic acid on the growth yield of yeasts differing in their resistance to preservatives. Applied and Environmental Microbiology 54, 2091-2095.

Wolosin, J. M. \& GinsBuRG, H. (1975). The permeation of organic acids through lecithin bilayers resemblance to diffusion in polymers. Biochimica et biophysica acta 389, 20-33. 